

$$
\text { ฮै }
$$




\title{
PRESERVATION OF FORESTS
}

AS A

\author{
MEASURE OF PUBLIC SAFETT
}

Address Delivered Before the Seventeenth

\section{National Irrigation Congress}

\author{
HELD AT \\ SP()KANE, WASHINGTON, U. S. A. \\ ACGist, 1904.
}

BY THE BRAZILIAN DELEGATE

L. BAETA-NEVES, Mining and Civil Engineer. 



\section{THE PRESERVATION OF FORESTS AS A MEASURE OF PUBLIC SAFETY.}

Address before the 17th National Irrigation Congress, Spokane, Wash., August, 1909.

by

\section{BAETA-NEVES}

Mining and Civil Engineer; Graduate of the Ouro Prete Mining School, Brazil; Chiel of the Technical Deparıment of the Directory of Railway and Public Works in Minas Geraes, Brazil; Member of the Historic and Geographic Instilute of the same state; Member of the National Geographic Society of Washington; Knight of Columbus; Honorary Member of the Rotary Club of Los Angeles. Cal.; Representative of the Brazilian Covernment before the Scientific Congresses I6th Irrigation and 3rd Dry Farming in America, and Vice-President and Corresponding Secretary of this Congress: Special Delegate of Brazil before the 17th National Irrigation Congress at Spokane, Wash., where, by selection, he addressed the meeting on behalf of the Foreign Represensatives.

I really foel gatal and excedingly homored in coming again before this congress and my pleasmpe is ereat in telling you onse more how mush I appleciate the warm wolcome of the North Amerian people. and how murb I have enjoyed the pleasant stay in this most hospitable (aity.

I come now with the same feelings and sentiment that I fried fo translate to yon on the opening session of this most important moeting full of very raluable lessons from any view point; on that fay I hail the ereat honol of speaking to you mo bohalf of the foroign dolegates of this anvention bringing greetings from the Bratian Government and from the different nations here represented. But now. allow me to say. Amerisans, and distimguished representatives of foreign contiuents and islands. that translating the good feelings and alture istir sentiment of the people of the eomntries of Columbus, I am woing to speak with my whole soml, my whole heart. on behalf of the saered rights of humanity. addressing you on at subject very dear to mo in which I have heen depply interested sinee my rhildhood: a subject on which I have leaned a sereat deal feom two men of moiversal reputation. who. for the eropy 
of the western hemisplere. Were born umbley the prosest sky of Ameriva-l mean Roosevelt and Gifforel Pinchot. I stamel for the forest, for the meservation of forests as a measure of public safety. Mr paler is in part an extract of a report that I sent to Brazil to be real this weok at the repmest of the th luternational American Medical coneress, held now at Rio 1), Janeiro "on the most efficacouns means of preventing and lessening the effects of periolical droughts." In that paper I wote about the lessons of the Irrigation Congress, which lessoms we are alrearly plofiting by, having imploved the Iroiwation projocts of whing I wrote the adchess printed in the por resilings of the 16th National Iropation congress. last year. I am ploased to say that in this report I emphasized also the

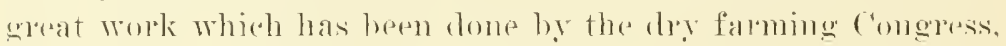
whose lessoms are the best to teach the people of the arid distruot of the world, how to nse profitable by the water, almost always so expensive and difficult to be obtained in such elistricts. Yom will fint on the last proceedings of the dry farming Concress at Cheyenme, a papere of mine on the combination

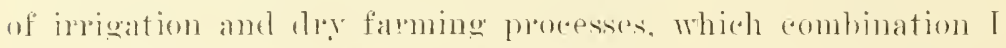
lhink will give the best results in renclerine more fit to sustain life a region subjoct to dromeht. To the merlioal Comgress. I

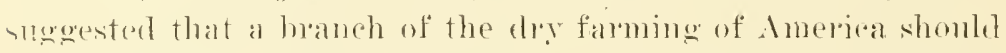
lo: estahlished in Brazil alcoorling to the wishes of its indefatigable sectetary my good fremel Mr. John T. Bums. Being

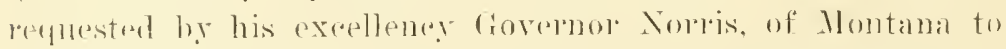
work in Baril. as a viep-president and corresponding seeretary

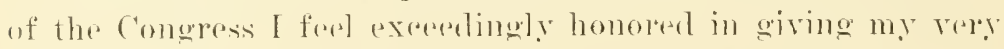
lest serviee 10 my bothers of North Americal, assinging them

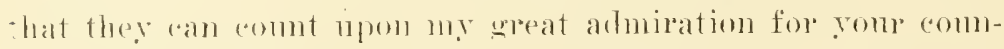
try. where I am living for one gear with my family always in alose tomeh with the Amerian family and people. Allow me to say. laclies and enentement that keeping the same love for my nalive lamel, in my heat, will have for ever a warm remen for the Amoxican people. But let me stop, ladies and exentlemen, of

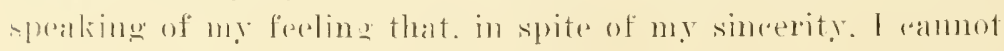

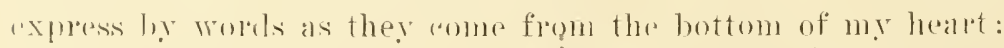

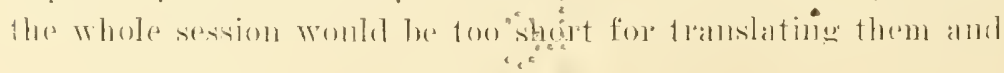


I must go back to the subject of my paper. lu my repost to the International Medical comeress I wreste also about the Cactus of Luther Burbank. of Califormia. and incielentally I called the attention of the Bratilian Enemeses to the recent pocess in whith the Enotish govermment is now interested. faceilitating the atmospherice precipitations for small water stuply neat the coast. alusing the deposit of der as has been pravtices in Gibmaltar I have learl somethine about this pro-

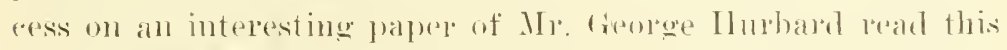

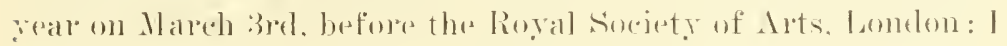
wote too about the forasts consichring them like I am about to to.

The importance of folests as moterotols of mankind is an incontroversible faret. and there is mo spilot. less observing as it may be, that has not motionis. orem slightly. somo influenee of the trees in benefitting life.

At rifferent fimes I have treated this innportant subject that impressed mo so much. in the national and foredon puess and in pulblic adebesses here in America, several times disensing the influenes of the treses mpon un life. Once speaking about the rombined work of medicine and engineeriug in the

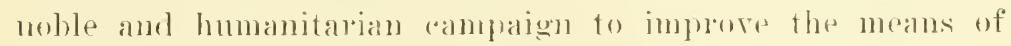
life on the surface of this planet. expereially to preserere and incerase the vigot of the people. I sairl in part:

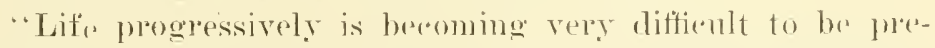
served in good comelitions beranse of the imessant exhamstion of elements that are favorable to it on the surface of the earth, where a continuous transformation is observed all over.

"The forests, the best protertors of our life are going fast. and from the molifiration that their clisappearano is bringing 10 the climate and to the natural anditions all orel the eath. will come serious trombles to the solntion of the sanitary probloms in the finture.

" It is necessary to nse intelligently so impoltant elements of life. without so barbarous destructions. because so fal as the present scientific knowledge is rontermed. there is no doubt, at all. that from the lack of the forest will come the greatest modifications in the meteorological conditions of the earth. and you know, the meteorological conditions - the weather- 
has the most positive influence on on life. This influence does not appear only on the health comditions, but, too, in the most complicate social phenomena.

"The olel proverb- Man is the som of his envilomments' -is a translation of a truth seientifically demonstrated. proving the weather's influence. It is truc that it means the law of adaptation. but the mviromments of man depenel entirely mpon the metromological conditions. Aroording to this law we romld, perhaps. hive sven under barl comditions of weather. but sureh condition womld bring an mulathy rondition of life. too.

"Professor Dexter" of the Iniversit! of Illinois. studying the mental and physiological intinence of the moteorological conditions, in one of his hooks. gives a comprehensire study of the question. proving the weather s influence on the oranic and intellertual life. the emotions, the literary sentiments, the individual comblnet. In proves principally that the change of meteorologiaral conclitions afferts the health more than anything alse.

"I Inder bad motemolowical conditions we never mould have the necessary reserve of eneror for the aomplete activity of life.

"And wood meteorological conditions can be gualanteed only by the preservation of forests. that. mulnapily for onr futmre,does not receire from the people the deserved attention."

Since the colonial time many Brazilians have been considering the forests from a sanitary riewpoint. The patriareh of omr independenre. José Bonifacio in 1815 wrote these phrases:

"What other productions of Mother Nature ought to de. sorve greater attention from the philosophers anil statemen than the forests and trees? Trees. Woul and timber: Onty these words. well meditated mpon ant understook, are enomgh to awaken on whole sensibilit.."

Besides other reasons there is a powerful one that makes necessary the protertion of forest - its great influence npon health. Health is all, and npon it reposes the happiness of peopte and the greatness and prosperity of the commeries.

On aceount of a rapid progress we must not sacrifice the forests as it has been done in many now romutries.

Any progress detrimental to the vital forces of nature, is 
negative, ephemeral : if one generation profits by it, the following one fatally will suffer its consequences.

'This axions, in my humble opinion. translates better the dreline ant disappealance of some nations that figured in antignity than any explanation wiven by the modern philosophy for the fact: and forethought atlises to profit by the practical lesson contained within it. preserving onr natural resources in order not to sacrifice to a temporary greatness the best neans of preserving life, which means are represented l, the forest.

The trees are great regulators of many conclitions of life, principally facilitating the atmosplerice precipitation and their profit. The afueous vapors penetrating the cool atmoswhere of the forest at the contact of the foliage of the trees. condense resolving into rain or dew and the water that falls on the soil. protected against evaporation by the shade, having' its smrface-flow impeted and its absorption facilitated by the roots, penctrates in greatest quantity into the land, guaranteeing the permanency and abmulance of the source that it forms.

The rainfall withont the protecting vegetation rapidly Hows on the surface soil formine the rmu-off, which takes from the earth the fertilizing homms, excavating the mountain and producing the destructive overtiow in the valley.

lin the comutries where ice and smow do not appear the regimen of the water coumses in a great measure depends upon the vogetation that rovers the head of the streams: and such an influence is as great as the porosity of the soil is small in the generative hasin of the somrces. If there is yet eontrovast which is progressively disappearing with more serions study abont some forests' influences, there is not, all over the rarth, any one who can soventifically eontest this truth that history and weopraphy, the farets of the past and the observation of the present so clearly confirm. The Nile, which comes from the heart of Afriva, born amone the virgin forests where fire and men never have penetrated. keeps today, in an average. the same How that it hat when it fertilized Egypt at the time of the Pharaohs.

The effects of forests do not appear in confined zones. 
Their influence is not bounded by a certain region, and the calamity coming from their derastation passes over the individual property affereting the public welfare. This is an incontestible truth that soience demonstrates and facts corroborate. Therefore there is no reason why protection of forest must be concerned to a certain extension, not affecting the private lands.

The individual right onght not to affect the high interests of the Union which onght to save its own future. guaranteeing hy the preservation of the natural resompes of the comntry, the general well-being of the present and future generations.

This rational theors, applied to the ase of forests, each day gains assent in this conntry being already arepted in the higher tribmals in favor of the legislation protecting such resompers. which lexislation is earnestly arlvocated by President Roosevelt, aceordingly it was adopted on March 10. 1903 by the supreme court of Maine, and on April 6th of the same year. the smpreme cont of the United States sustained it, confirming the opinion of the cont of errors and appeals of New Jersey.

To the glory of us Brazilians this principle is the confirmation of a doctrine of which I spoke last here at Albuquercue. promulgated in 1892 by the eminent Brazilian. 1)r. Franciseo Satmono Rodrignes de Brito. who wrote:

"The aromment against such laws has no pason for being. heranse the owner of the land is only a steward of the soil that was entrusted to him by the past generations: he is the depository of lands as he is a depository of capital. and thus. as it has a soedal origin. territorial property must have a social application. in attending to collective interest: and these require the indiridual effort of each man to preserese and improve on the planet the necessary means of living. anong which are the preservation and replantation of forests. that may keep the necessary moisture for regnlar rainfall and the normal dislribution of water. detaining it among their roots and not permittile the destructive orerfows that talie from the soil the fertilizing hnmus. The argument has no reason for being, also. beranse the juterest of the family itself requires providence against the prodigal nember who steals from his own children 
the inheritaner from the past, giving to this improvident an egotistical father only the income of it a and as it happens with the inheritance. legislative enatment must pombate the curestion of lands for the interest of the social commmity that has a great attamment from the Past. and comprehenling the L'resent and the Future."

The arements of President Roosevelt are very similar to those of the illustrions. Brazilian engineer and the same thing an be said in reard to the reasons presented by the Supreme court of the Lnited states as quoted by the American l'resident:

"The State. as quasi-sovereign and representative of the interest of the publice. has a standing in eomet to protect thr atmosphere. the water and forests either in its temitory, irrespective of the ascent or descent of the private owner of the land most immediately concerned."

I am deeply convineed that the eonscientions scruples of a great many of om rminent legislators and loyal men in ac"epting this clowtrine lie only in the fact that they are always busy with something else. never dedicating themselves to any serious study of the forests in their relations to life and the progress of comntries; they have never comsidered that, on arecount of smeh relation. the sacred rights of humanity, the life of our chikhen and future generations resmire a direct ano immediate protertion for the trees. which protection is undoubtedly a measure of public safety. And really smeh a protection is as important as any other measure that may prevent the invasion and spreat of some epirlemic discase.

To the th Latin-American congress I moved that all possible eftort should be made to have Brazil and all nations represented at the congresis acerpted the proposition that is fomd in my aldress of forests last year, which proposition I write now as follows:

"Preserzation of forests in many atays necessary, must be considered as a measure of public safety and it is of urgent necessity to maintain the permanency and abundance not only of the stream fiow, but, of the underground waters." (1) 
This proposition. ladies and gentlemen, will do some good for onr forests when thoronghly aceepted in the countries where the question of right of property has been an obstacle to the protection laws for saving the trees on the private lands.

I make an appeal to you. gentlemen. of all different nations here represented to hring with yon the ideas contamed in this paper whose value lies only on the strong convietion with which I wrote it.

Let us be mited all over the world in this yreat and noblest campaign for the life of mankind, for the life of our own "hildren, the water. the pmo air, the shade of relief of fatigne. the timber. in resume, the life itself. Let ns profit by the great lessons of Gifford Pinchot, accepting the wise advise of greatest men of the past and present generations. And may this alarm-cry aronse the energies of the present for the solntion of the great problem of the future.

\section{MEANS ADVISED TO PREVENT THE CUTTING OF FOR- ESTS IN BRAZIL.}

After the approbation of the proposition contained in the first part of my aldress considering the protection of the forests als a masure of public safety, we must have some restrietion from the states in regard to the nse of the generative land of courses, establishing the protective areas, even approximately. arecording to the good sense, putting them under a provisory poline of the tax collectors and the patriotism of the people. until we can get the resonres for a most effective police.

We must get annually from the Federal Congress some appropriation, howerer small. to start the National Forestry Reservation at the head of the great and navigable rivers. progressively enlarging surh reservation until it has a sufficiant extension.

I think that in general the forests would he preserved if the people knew how to use them systematically if efficient means of preservation of timber conkl be obtained. in order to use the softer and light wool as gond material, avoiding, as said by the illnstrions engineer. Joarnim Julio Proenea, the 
dratation of the virenin forests for haldwooks to be emploged in construction of certain importance, principally railroals: if we could plant good speries. wowne fast to be nsed as finel and goud timber. for instance. the encalyptus as is being done in California, and was atristel in Minas Gerates by the dis-

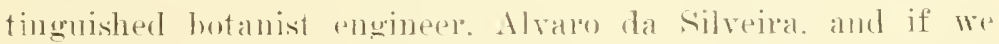
could stop of diminish the charing of formste of old proceses of burning the forests for tinel amet angeroltural purposes by divnlging the scoentitic processos of rultivation. and protit by nsing green wool as at fuel in wreat factories. using ary stoves heated by the fulluace wases. as established by the leceased President Joan Pinheiro in his farotory at Caeté. Minas Geraes. Brazil.

From these (onsiderations we have many suresestions how to protect the treses. but. cortainly. the sugersted measmes and those profitahle ones fomed in many forestry codes in om states. must not be takon only hy the Lrion. Whose service, as I said before. must he as simple and economir as possible iil orter to be stable.

The Federal Government in areondaner with the states must help the development of the instruction on forestry. establshing spesial forostry sarlons. howerer small. comected with botanical hranch is the enginesping courses. for better knowledor and trial of speceses of rapid growth. suitable for construction and railroal ties: must promote leplantion of resistant trees snch as encalyptus in the arid region. principally where the somres permanently or temporauly appear; must promote the employing of light and white soft timber by griving preminms to the inventor of the best and nost eromomic poro"ess for its preservation, and finally, must make every possible propaganda he publication of shont and practical papers and so on among farmers on the influmce and ralue of the forests.

(1) In my book on the water supply and sewers of Caxambu, Minas Geraes, Brazil, I explained the infuence of the forests upon the underground water in a chapter under" the title "Preservation of the sources." 







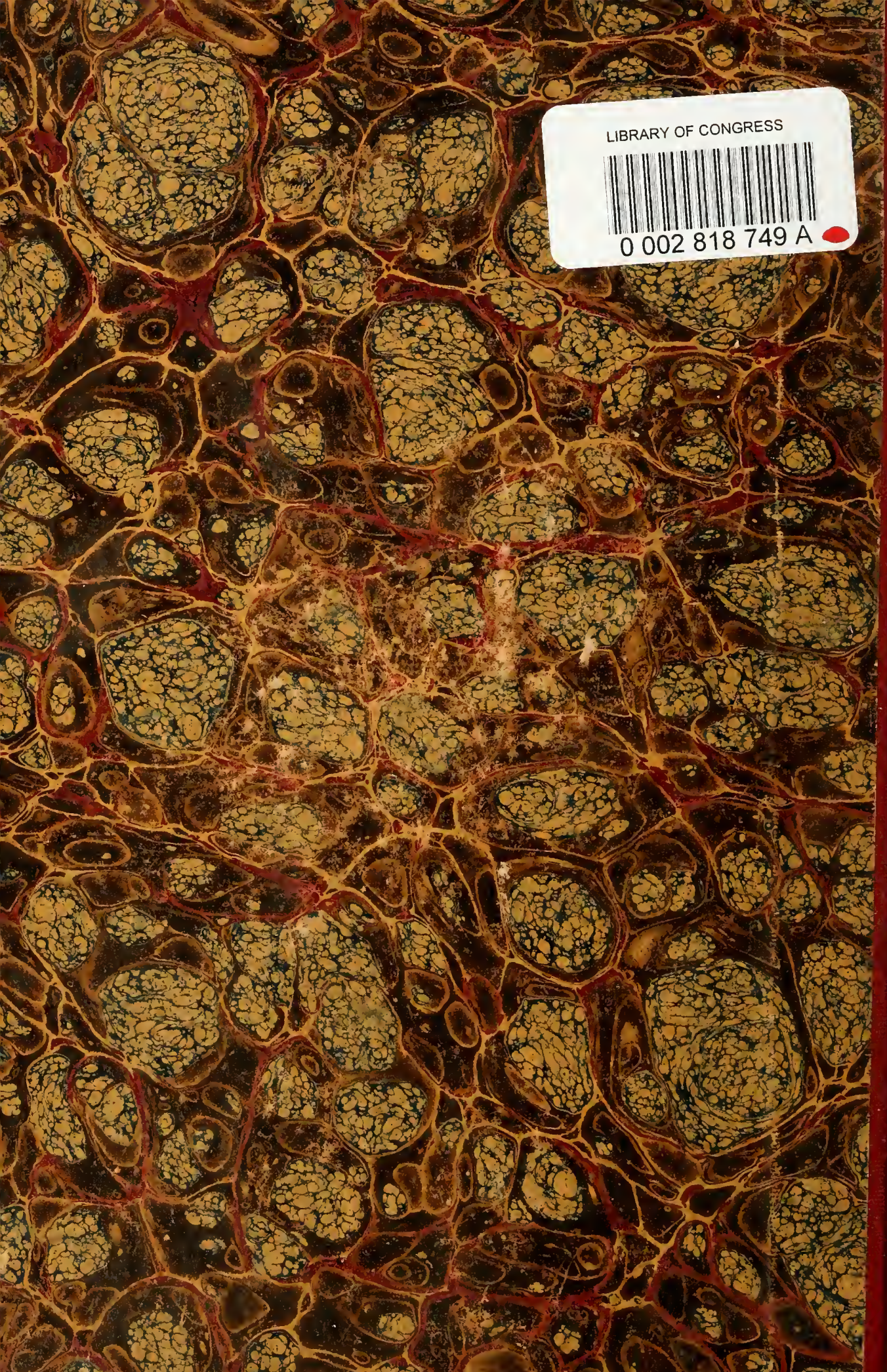